ÇOMÜ Uluslararası Sosyal Bilimler Dergisi 3 (2), 265-291 , 2018

COMU International Journal of Social Sciences 3 (2), 265-291 , 2018

\title{
Lojistik Faaliyetlerin Yönetimi ve Maliyetlemesi: TR22 Bölgesinde Bir Araştırma *
}

\author{
Metin ATMACA** \\ Zeliha SEVIM ${ }^{* * *}$
}

Öz

Lojistikkavramının işletmeler tarafından önemlibiryere sahip olması küreselleşme ve teknolojinin artmasıyla birlikte ortaya çıkmıştır. Lojistik, hammadde temininden nihai ürüne ve müşteriye teslim edilmesinden geri bildirim sürecini de içine alan bir kavram haline gelmiştir. Bu nedenle etkin bir şekilde yönetilen lojistik, maliyetleri etkileyecektir. Bu durum işletmelerin rekabet edilebilirliği artıracak veya azaltacaktır. Bu çalışmanın amacı, işletmelerin lojistik faaliyetleri, maliyetleri ve dış kaynak kullanımı hakkında bilgi edinmektir. Çalışmada anket tekniği kullanılmış olup TR22 Bölgesinde bir araştırma yapılmıştır.

Anahtar Kelimeler: Lojistik, Lojistik Faaliyetler, Lojistik Yönetimi, Lojistik Faaliyetlerde Maliyetleme.

\section{Logistic Operations Management and Costing: A Research in TR22 Region}

\begin{abstract}
Significance of logistics has increased following the globalization and fast pace of development in the technological area. The concept of logistics includes supplying raw materials to delivering final product and possible feedback. Therefore, effectively managed logistics will affect costs. Thus, the competitiveness of businesses will increase or decrease. The purpose of this study is to analyze logistics activities, costs and outsourcing of businesses. A research was conducted in the study in the TR22 region of Turkey by using survey technique.
\end{abstract}

\footnotetext{
* Bu çalışma Çanakkale Onsekiz Mart Üniversitesi Sosyal Bilimler Enstitüsü İşletme Yüksek Lisans öğrencisi Zeliha SEVİM tarafından 2017 yılında Doç. Dr. Metin ATMACA danışmanlığında Enstitü’ye sunulan “Lojistik Faaliyetlerin Yönetilmesi ve Maliyetlemesi:TR22 Bölgesinde Bir Araştırma” adlı yüksek lisans tezinden üretilmiştir.

** Doç. Dr. Çanakkale Onsekiz Mart Üniversitesi Biga İ.İ.B.F. İşletme Bölümü matmaca@gmail.com

*** Çanakkale Onsekiz Mart Üniversitesi SBE İşletme Yüksek Lisans zelihaayan17@hotmail.com
} 
Keywords: Logistics, Logistics Activities, Logistics Management, Costing in Logistics Activity.

\section{GIIRIS}

Lojistik kavramı günümüzde hammaddenin temin edilmesi, üretim yerine getirilmesi, nihai ürün haline gelmesi, depolanması, talep tahmini, müşteri hizmetleri, envanter yönetimi, sipariş takibi, gümrükleme ve müşteriye tam zamanında ulaştırma gibi tüm faaliyetleri içine alan bir kavram haline gelmiştir. Günümüzde küreselleşme ile birlikte tüketici taleplerinin hızlı bir şekilde değişmesi işletmeleri farklı arayışlara sürüklemiştir. Lojistik açıdan ele alınan bu değişim, işletmelerde lojistik faaliyetlerin yönetilmesi ve etkin bir maliyet analizinin yapılması gerekliliğini ortaya çıkarmıştır.

TR22 bölgesi (Çanakkale ve Balıkesir) esas alınarak yapılan bu çalışmada lojistik faaliyetler ve maliyetlere ilişkin kısaca açıklama yapılmıştır. Daha sonra literatür incelemesi yapılmış olup araştırmanın amacı, önemi, kısıtları ve bulguları sunulmuştur. Yüz yüze anket tekniği uygulanan bu çalışmada katılımcılara ait demografik bilgiler ve likert tipi sorulara yer verilmiştir. Bu ifadelere Frekans ve Güvenilirlik analizi uygulanmıştır. Likert ölçekli sorular ile katılımcıların demografik özellikleri arasında ilişkiye bakılarak Varyans Analizi ve bu analizi destekleyen Tamhane ve Scheffe Analizleri yapılmış olup sonuçlar tabloda gösterilmiş ve yorumlanmıştır.

\section{LOJİSTIKK VE LOJİSTİK FAALIYYETLER}

\subsection{Lojistik Kavramı}

Lojistik kavramı ile ilgili birçok tanım mevcuttur. Bu tanımlardan bazıları ise aşağıdaki gibidir.

Fransızcadan türemiş olan lojistik kavramı, askeri kökenli bir kavram olup ordunun savaşı kazanması için gerekli olan tüm hizmeti vermek olarak tanımlanabilir. Bu tanımla birlikte lojistik ilk olarak taşıma alanında faaliyet göstermeye başlamıştır. Ancak lojistik, askeri kökenli bir kavram olmasına rağmen günümüzde işletmeler tarafindan çok kullanılan ve önem taşıyan bir kavram olmuştur. Böylece zamanla lojistik sadece taşıma değil hammadde, malzeme gibi hizmetlerin temin edilerek saklanmasını, üretim sürecini ve nihai ürünlerin müşterilere iletilmesi ile geri bildirimler için gerekli tüm işlemleri içine almıştır (Tokay vd. 2011: 227).

Lojistik Yönetimi Konseyi (Council of Logitics Management- CLM) tarafından yapılan tanıma göre lojistik, "müşteri ihtiyaçlarını karşılamak için malların, hizmetlerin veya ilgili bilgilerin üretim noktasından tüketim noktasına verimli bir şekilde akışını ve aynı zamanda depolanmasını planlayan, yürüten ve kontrol eden tedarik zinciri sürecinin bir 
aşaması” olarak tanımlanmıştır (Deran vd. 2014: 6).

Lojistiğin en çok bilinen 7 doğrulu tanımı ise şöyledir; “doğru ürünün, doğru miktarda, doğru şekilde, doğru yerde, doğru zamanda, doğru fiyatla, doğru müşteriye ulaştırılması”dır (Gümüş 2007:3).

Lojistik, işletme içinde ve dişında tüm süreçlerdeki malzeme ve ürünlerin hareketini ifade eder. Bu hareket işletme içinde bir süreçtir. Üretim, mal ve malzeme taşıma, satış süreci, geri dönüşüm, müşteri memnuniyeti ve iş rekabetini kapsamaktadır (Tseng vd. 2005: 1658).

\subsection{Lojistik Faaliyetler}

Lojistik faaliyetler, lojistik süreç ile başlayan sipariş verme, satın alma, taşıma, depolama, sigortalama, sevk etme, yükleme, boşaltma, paketleme, talep tahmini, dağıtma, müşteri hizmetleri ve tersine lojistik sürecinde yaşanan tüm faaliyetleri kapsamaktadır (Tokay vd. 2011: 227). Lojistik yönetimi içindeki faaliyetlerin birleştirilmesi, müşteri isteklerinin karşılanması, tedarik edilmesi, üretim ve dağıtım işlemlerindeki gecikmelerin engellenmesi, maliyetlerin kontrol edilerek azaltılması açısından önemlidir (Özcan 2008: 281).

Lojistik faaliyetlerin ürünlere değer katan üç işlemi vardır. Bunlar (Şengel 2012: 28):

i. Konum: Taşıma maliyetlerini de kapsayan bu işlem ürünlerin müşteri açısından daha düşük değerli olduğu yerlerden, daha yüksek değerli olduğu yerlere taşınması sayesinde konum değerini arttırır.

ii. Zaman: Envanter bulundurma maliyetlerini kapsayan bu işlem, ürünlere ihtiyaç duyuluncaya kadar depolarda bekletilmesi ve tüm süreçlerin daha verimli yürütülmesidir.

iii. Yapı: Ürünlerin talep edildiği ölçülerde hazırlanarak, sipariş değeri eklenmesidir.

Lojistik süreç sonucunda oluşan lojistik faaliyetler ve çıktıları şekil 1'de gösterilmiştir. 


\section{Şekil 1: Lojistik Sistem}

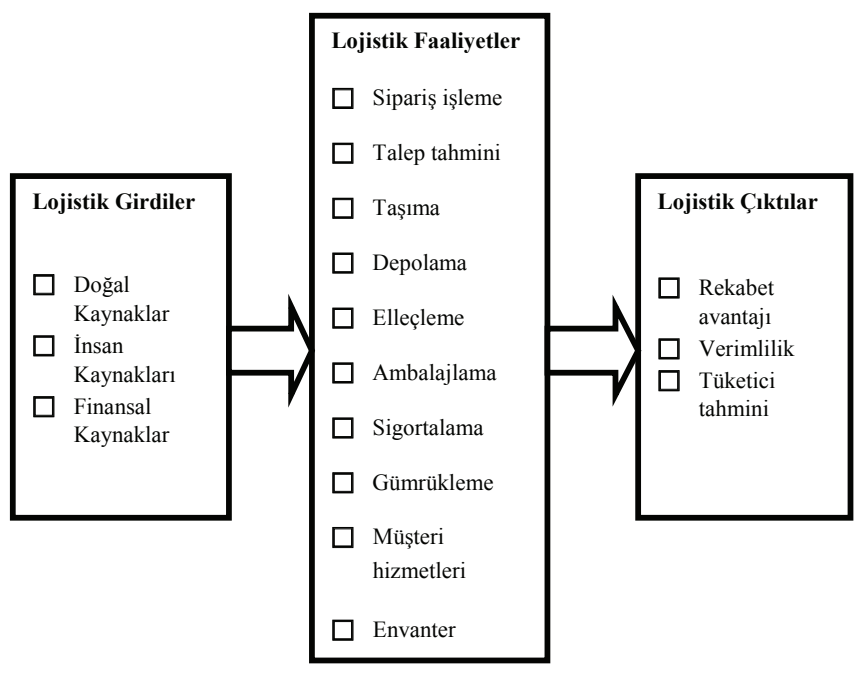

Kaynak: (Demir 2008: 26)

Lojistik faaliyetler işletmelerin faaliyet alanları, yönetimleri, hammadde ve pazara yakınlıkları gibi birçok faktörün etkisiyle planlanarak işlevsel hale getirilirler. Böylece lojistik faaliyetler üzerinde yapılacak değişiklikler, işletmelere rekabet üstünlüğü sağlayacaktır (Taşkın ve Durmaz 2012: 39-40).

İşletmelerde etkin bir şekilde yönetilen lojistik faaliyetlerin sağlayacağı yararlar aşağıdaki gibidir ( Deran vd. 2014: 23):

- Maliyet yönetiminde ve planlamada etkinlik artmaktadır.

- Zaman yönetiminin önemi artmaktadır.

- Küreselleşmeyle birlikte zamana ve müşteriye uygun yöntemler oluşturulmalıdır.

- Teknolojik yatırımlar ve alt yapı hızlı bir şekilde gelişmektedir.

\section{LOJİSTİK FAALİYETLERİN MALIYYETLEMESİ}

Lojistik faaliyetlerin meydana gelmesi sırasında ayrı ayrı işletmeye bir maliyeti vardır. $\mathrm{Bu}$ maliyetlere de lojistik maliyetler denilmektedir. Maliyet, belirlenen hedefe ulaşmak için katlanılan fedakârlıkların parasal tutarıdır. Bu tanıma göre, lojistik maliyetler, lojistik faaliyetlerin yerine getirilmesi sırasında katlanılan fedakârlıkların parasal tutarıdır denilebilir (Tokay vd. 2012: 83). Bir işletmede lojistik maliyetlerin açık ve net bir şekilde 
görülebilir olmasının birden fazla faydası ve amacı vardır. Bu amaçlar aşağıdaki gibidir (Demir 2006: 120):

- Direkt maliyetlerin belirlenmesi,

- Ürün-miktar ilişkisinin daha iyi anlaşılması,

- Maliyetleri minimum seviyeye düşürme firsatı,

- Yeni teknolojik yatırımların belirlenmesi,

- Maliyetlerin daha çok önemsenmesi.

Üretim noktasından tüketim noktasına kadar geçen sürede bir ürün veya hizmet akışını kolaylaştıracak önemli lojistik faaliyetler; "müşteri hizmetleri, talep tahmini, envanter yönetimi, malzeme taşıma, paketleme, servis desteği, pazar seçimi, tedarik, tersine lojistik, nakliye ve depolama" gibi işlemleri içerir. Bu faaliyetlerin her biri tedarik zinciri yönetiminin bir parçasıdır. Bununla birlikte, lojistik faaliyetlerin toplam maliyetini iyice değerlendirmek için ilgili tüm faaliyetler hesaba katılmalıdır (Lin vd. 2001: 705).

\section{Şekil 2: Lojistik Maliyetlerin Yapısı}

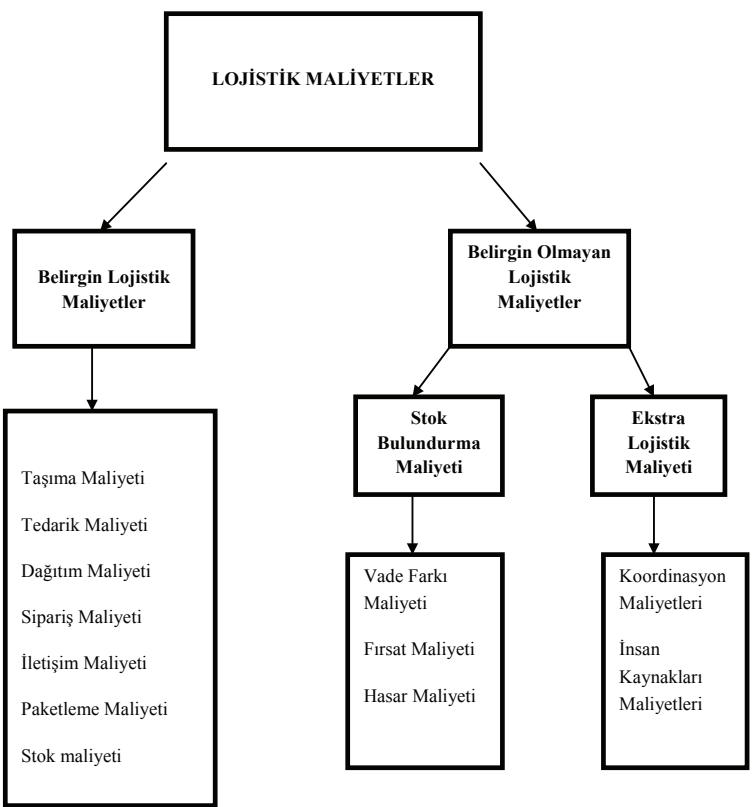

Kaynak: (Tokay vd.2011: 271). 
Genel olarak, lojistik maliyetler, sektör yapısına, sipariş türüne/miktarına ve şirketin çalışma yöntemlerine bağlı değişkenlik gösterebilir. Lojistik maliyetler ayrıntılı olarak sinıflandırıldığında aşağıdaki gibidir (Manunen 2000: 54):

- Taşıma maliyetleri

- Dağıtım maliyetleri

- Gümrükleme maliyetleri

- Depolama maliyetleri

- Satın alma maliyetleri

- Sipariş verme maliyetleri

- $\quad$ Ödeme işlemleri maliyetleri

- Satış maliyetleri

- Tersine lojistik maliyetleri

Lojistik maliyetler analiz edilirken, lojistik ihtiyaçları karşılamak için katlanılan tüm maliyet kalemleri birbirleriyle bağlantılı olarak incelenmelidir. Genelde işletmelerde lojistik ve dağıtımı birleştiren yaklaşımların kabul edilmesinin zor olmasının nedenlerinden biri de uygun maliyet bilgilerinin yetersiz oluşudur. Maliyet bilgilerinin yetersiz olması, lojistik zincirindeki her maliyet kaleminin tek tek incelenmesini etkileyecektir. Bu durumda zincirin içinde yer alan tüm maliyet kalemleri olumsuz olarak etkilenip toplam kar üzerinde negatif etki yapacaktır (Hacırüstemoğlu ve Şakrak 2002: 111-112).

\section{LITERATÜR ARASTTIRMASI}

Lojistik faaliyetler ve maliyetler üzerine yapılan bazı çalışmalara yönelik literatür taraması aşağıdaki tablo 1'de gösterilmiştir. 


\section{Tablo 1: Lojistik Faaliyetlerin Yönetimi ve Maliyetlemesi Literatür Özeti}

\begin{tabular}{|c|c|c|c|}
\hline $\begin{array}{l}\text { Çalışmayı } \\
\text { Yapan/ } \\
\text { Yapanlar }\end{array}$ & Çalışma Yöntemi & Çalışma Kapsamı & Bulgular \\
\hline $\begin{array}{l}\text { Karacan ve } \\
\text { Kaya (2011) }\end{array}$ & $\begin{array}{l}\text { Anket soruları likert } \\
\text { ölçeğine göre hazırlanmıştır. }\end{array}$ & $\begin{array}{l}\text { T.C. Ulaştırma Bakanlığı } \\
\text { bünyesinde faaliyet } \\
\text { gösteren ve belge almış } \\
\text { firmalar ve organize } \\
\text { sanayi bölgelerinde } \\
\text { faaliyet gösteren üretim } \\
\text { işletmeleri. }\end{array}$ & $\begin{array}{l}\text { Lojistik faaliyetler sonucu } \\
\text { ortaya çıkan maliyetlerin tek } \\
\text { tek hesaplanması gerektiği } \\
\text { ve taşıma maliyetlerinin en } \\
\text { çok paya sahip olduğu ortaya } \\
\text { çıkmıştır. }\end{array}$ \\
\hline Yaprak (2010) & $\begin{array}{l}\text { 5’li likert ölçeği ile anket } \\
\text { soruları hazırlanarak SPSS } \\
\text { programı aracılığı ile analiz } \\
\text { edilmiştir. }\end{array}$ & $\begin{array}{l}\text { Kayseri Organize Sanayi } \\
\text { Bölgesi'ndeki üretim } \\
\text { işletmeleri. }\end{array}$ & $\begin{array}{l}\text { Lojistik faaliyetlerin işletme } \\
\text { içinde gerçekleştirilmesi ve } \\
\text { etkin olarak yönetilmesi, } \\
\text { işletmeleri başarıya ulaştırdığ } 1 \\
\text { ve rekabet avantajı sağladığı } \\
\text { tespit edilmiştir. }\end{array}$ \\
\hline Ener (2010) & $\begin{array}{l}\text { Sıralı, likert ölçekli sorular } \\
\text { ve semantik farklılık ile } \\
\text { anket soruları hazırlanmış } \\
\text { olup, çapraz tablolar ve } \\
\text { Ki-Kare bağımsızlık testi } \\
\text { kullanılmıştır. }\end{array}$ & $\begin{array}{l}\text { Mersin Ticaret ve Sanayi } \\
\text { Odası ve Mersin Deniz } \\
\text { Ticaret Odası'na kayıtlı } \\
\text { lojistik firmalar. }\end{array}$ & $\begin{array}{l}\text { Teslimatın tam zamanında } \\
\text { gerçekleşmesi ile müşteri } \\
\text { memnuniyetinin ve işletme } \\
\text { verimliliğinin arttığ tespit } \\
\text { edilmiştir. }\end{array}$ \\
\hline $\begin{array}{l}\text { Kayabaşı } \\
(2007)\end{array}$ & $\begin{array}{l}\text { Korelasyon, regresyon, } \\
\text { varyans, bağımsı örnek } \\
\text { t-testi, faktör analizi, frekans } \\
\text { dağılımları ve yüzde analizi. }\end{array}$ & $\begin{array}{l}\text { İstanbul Sanayi Odası } \\
\text { tarafından belirlenen ilk } \\
\text { ve ikinci beş yüz üretim } \\
\text { işletmesi. }\end{array}$ & $\begin{array}{l}\text { Lojistik faaliyetler sonucu } \\
\text { oluşan işlevlerin çeşitliliği } \\
\text { ve işletmeye sağladığı katma } \\
\text { değerler de dikkate alındığında } \\
\text { işletme açısından lojistiğin } \\
\text { önemli olduğu tespit edilmiştir. }\end{array}$ \\
\hline $\begin{array}{l}\text { Taşkın ve } \\
\text { Durmaz (2012) }\end{array}$ & $\begin{array}{l}\text { Anket yöntemi. Varyans, } \\
\text { korelasyon, regresyon } \\
\text { analizi ve t-testi. }\end{array}$ & $\begin{array}{l}\text { Yurt içi kargonun Kütahya } \\
\text { sinırları içindeki kurumsal } \\
\text { müşterileri. }\end{array}$ & $\begin{array}{l}\text { İşletmelerin üretmiş oldukları } \\
\text { mal veya hizmetlerin } \\
\text { değerleri, müşterilerin } \\
\text { istediği yer ve zamanda hazır } \\
\text { bulundurulmalarına bağlıdır. } \\
\text { Müşteriye zamanında teslim } \\
\text { edilmeyen ürünlerin müşteri } \\
\text { açısından hiçbir değeri olmadığ } \\
\text { kanısına varılmıştır. }\end{array}$ \\
\hline $\begin{array}{l}\text { Deran vd. } \\
(2014)\end{array}$ & $\begin{array}{l}\text { Örnek Olay İncelemesi } \\
\text { (Faaliyet tabanlı } \\
\text { maliyetleme) }\end{array}$ & $\begin{array}{l}\text { Özel bir kalsit maden } \\
\text { işletmesi }\end{array}$ & $\begin{array}{l}\text { Kaynaklar ve bu kaynakları } \\
\text { tüketen faaliyetler tespit edilerek } \\
\text { lojistik faaliyetlere harcanan } \\
\text { maliyetler belirlenmiştir. }\end{array}$ \\
\hline Gümüş (2009) & $\begin{array}{l}\text { Örnek Olay İncelemesi } \\
\text { (Faaliyet tabanlı } \\
\text { maliyetleme) }\end{array}$ & $\begin{array}{l}\text { Ulusal ve uluslararası } \\
\text { boya sektöründe faaliyet } \\
\text { gösteren bir işletme }\end{array}$ & $\begin{array}{l}\text { İşletmelerin kullandığı } \\
\text { lojistik faaliyetlerin rekabet } \\
\text { edilebilirlikte ve işletme karı } \\
\text { ile direkt bir ilişkisinin olduğu } \\
\text { görülmüştür. Diğer taraftan } \\
\text { lojistik faaliyetlerde hem hizmet } \\
\text { düzeyini en üst seviyeye çıarıp } \\
\text { hem de maliyetleri düşürmek } \\
\text { için bu faaliyetlere bir bütün } \\
\text { olarak bakılması gerektiği } \\
\text { kanısına varılmıştır. }\end{array}$ \\
\hline
\end{tabular}




\section{ARAȘTIRMANIN METODOLOJISİ}

Çalışmanın bu bölümünde araştırmanın konusu, amacı, önemi, yöntemi, evren ve bulgularına yer verilmiştir.

\subsection{Araştırmanın Konusu ve Amacı}

Araştırmanın konusu, lojistik yönetiminin işleyişi, lojistikte temel faaliyetler ve bu lojistik faaliyetler sonucu oluşan maliyetler üzerine bir anket çalışması yapılarak değerlendirilmesidir.

$\mathrm{Bu}$ çalışmanın amacı ise, işletmelerin lojistik faaliyetler ve maliyetleri hakkında ne kadar bilgi sahibi olduklarını, lojistik faaliyetlerin hangilerini kendi bünyesinde veya dış kaynaktan gerçekleştirdiklerini belirlemektir.

\subsection{Araştırmanın Önemi}

$\mathrm{Bu}$ araştırmanın önemi, lojistik faaliyetlerin, işletmelerin hem üretim öncesi hem de üretim sonrası oluşan maliyetler açısından önemli bir kalem olmasından dolayı, TR22 bölgesinde faaliyet gösteren işletmelerin, üretim veya hizmet süreci boyunca kullanmış oldukları lojistik faaliyetler ve maliyetler hakkında araştırma yapmaktır.

\subsection{Araştırmanın Yöntemi}

Anket formu literatür taraması sonucu belirtilen kaynaklardan faydalanarak ve gerçekleştirilecek çok değişkenli analiz tekniklerinin kullanılmasına olanak sağlayacak şekilde, 5’li likert ölçeği düşünülerek hazırlanmıştır. Likert tipi ifadeler 1=Kesinlikle Katılmıyorum, 2=Katılmıyorum, 3=Kararsızım, 4=Katılıorum ve 5=Kesinlikle Katılıyorum biçiminde kodlanmıştır.

Anket formu iki bölümden ve toplam 29 adet sorudan oluşmaktadır. İlk bölümde beş soru "İşletmenin Genel Bilgileri” ile ilgili demografik sorular, ikinci bölümde ise 24 soru vardır. Anket aracılığı ile elde edilen veriler SPSS istatistik programı ile analiz edilmiştir. Araştırmada kullanılan tüm anket sorularına güvenilirlik analizi yapılmıştır. Cronbach's Alpha değeri hesaplanmıştır. Demografik ve likert ölçekli sorular Frekans analizine tabi tutulmuştur. Likert ölçekli sorular ile katılımcıların demografik özellikleri arasında ilişkiye bakılarak Tek Yönlü Varyans Analizi (Anova), Tamhane ve Scheffe Analizleri yapılmıştır. Sonuçlar değerlendirilmiş ve yüzde oranları her biri için ayrı olarak gösterilmiştir.

\subsection{Araştırmanın Evren ve Örneklemi}

Araştırmanın evrenini Çanakkale Ticaret ve Sanayi Odası ile Balıkesir Ticaret ve Sanayi Odasına bağlı, faaliyet gösteren işletmeler oluşturmaktadır. TOBB Sanayi Veri Tabanına göre TR22 bölgesinde faaliyet gösteren firma sayısı yaklaşık 1250 civarındadır. Çalışan 
sayısı 5 ve üzeri olan işletmelere uygulanmış olup toplamda 205 ankete geri dönüş yapılmıştır.

\subsection{Araştırmanın Bulguları ve Değerlendirme}

\subsubsection{Araştırmaya Katılanlara Yönelik Demografik Dağılımlar}

Ankete katılan işletmelerin, hukuki durumu, faaliyet alanı, faaliyet süresi, çalışan sayısı ve anket formunu dolduran yetkili kişinin firmadaki görevi ile ilgili bilgiler sırasıyla tablolar şeklinde aşağıda gösterilmiştir.

Tablo 2: Firmaların Hukuki Durumuna Göre Dağılımı

\begin{tabular}{|l|r|r|r|}
\hline Hukuki Durum & S1klık & Yüzde & \multicolumn{1}{|l|}{ Birikimli Yüzde } \\
\hline Limited & 102 & 49.8 & 49.8 \\
\hline Anonim & 83 & 40.5 & 90.2 \\
\hline Diğer & 20 & 9.8 & 100.0 \\
\hline Toplam & 205 & 100.0 & \\
\hline
\end{tabular}

Tablo 2'de ankete katılan firmaların hukuki durumuna göre Limited şirketler \%49.8, Anonim şirketler $\% 40.5$ ve bunların dişında kalan işletmelerin ise \%9.8 olduğu görülmektedir. Çalışmaya katılan Limited şirketler anket sayısının yaklaşık olarak yarısını oluşturmaktadır.

Tablo 3: Firmaların Faaliyet Alanına Göre Dağılımı

\begin{tabular}{|l|r|r|r|}
\hline Faaliyet Alanı & Sıklık & Yüzde & \multicolumn{2}{|l|}{ Birikimli Yüzde } \\
\hline Hizmet & 24 & 11.7 & 11.7 \\
\hline Üretim & 131 & 63.9 & 75.6 \\
\hline Ticaret & 44 & 21.5 & 97.1 \\
\hline Diğer & 6 & 2.9 & 100.0 \\
\hline Toplam & 205 & 100.0 & \\
\hline
\end{tabular}

Tablo 3’e bakıldığında ankete katılan firmaların faaliyet alanına göre hizmet sektöründe olanlar \%11.7, üretim sektöründe olanlar \%63.9, ticaret sektöründe olanlar \%21.5 iken \%2.9'unu ise bunların dışındaki sektörlerde faaliyet gösteren firmaların oluşturduğu görülmekte olup çalışmada üretim sektöründe olan firmalar çoğunluktadır. 
Tablo 4: Firmaların Faaliyet Süresine Göre Dağılımı

\begin{tabular}{|l|r|r|r|}
\hline Faaliyet Süresi & Sılklk & Yüzde & Birikimli Yüzde \\
\hline 1 Yldan Az & 2 & 1.0 & 1.0 \\
\hline $1-5$ Yll & 34 & 16.6 & 17.6 \\
\hline $6-10$ Yll & 43 & 21.0 & 38.5 \\
\hline $11-15$ Yll & 24 & 11.7 & 50.2 \\
\hline $16-20$ Yll & 23 & 11.2 & 61.5 \\
\hline 20 Yll ve Üzeri & 79 & 38.5 & 100.0 \\
\hline Toplam & 205 & 100.0 & \\
\hline
\end{tabular}

Tablo 4'de ankete katılan firmaların faaliyet sürelerine göre dağılımı verilmiştir. 1 yıldan az süredir faaliyet gösteren firmalar \%1, 1 ile 5 yıl arası faaliyet gösteren firmalar \%16.6, 6 ile 10 yıl arası faaliyet gösteren firmalar \%21, 11 ile 15 yıl arası faaliyet gösteren firmalar \%11.7, 16 ile 20 yıl arası faaliyet gösteren firmalar \%11.2 ve 20 yıl ve üzeri faaliyet gösteren firmalar ise \%38.5'lik dilimi kapsamaktadır.

\section{Tablo 5: Firmaların Çalıșan Sayısına Göre Dağılımı}

\begin{tabular}{|l|r|r|r|}
\hline \multicolumn{1}{|c|}{ Çalıșan Sayısı } & Sıklık & Yüzde & \multicolumn{1}{c|}{ Birikimli Yüzde } \\
\hline 10 Kişiden Az & 25 & 12.2 & 12.2 \\
\hline 11-50 Kişi & 94 & 45.9 & 58.0 \\
\hline 51-100 Kişi & 34 & 16.6 & 74.6 \\
\hline 101-150 Kişi & 16 & 7.8 & 82.4 \\
\hline 151-200 Kişi & 11 & 5.4 & 87.8 \\
\hline 201-250 Kişi & 4 & 2.0 & 89.8 \\
\hline 250 ve Üzeri & 21 & 10.2 & 100.0 \\
\hline Toplam & 205 & 100.0 & \\
\hline
\end{tabular}

Tablo 5'de ankete katılan firmalarda çalışan kişi sayısı 10 kişiden az olanlar \%12.2, 11 ile 50 kişi olanlar \%45.9, 51 ile 100 kişi olanlar \%16.6, 101 ile 150 kişi olanlar \%7.8, 151 ile 200 kişi olanlar \%5.4, 201 ile 250 kişi olanlar \%2, 250 ve üzeri olanların dağılımı ise \%10.2'dir. Çalışmaya katılanlara bakıldığında çoğunluğu (94 firma) 11 ile 50 kişi arası çalışanı bulunan firmaların oluşturduğu görülmektedir.

Tablo 6: Çalışanların Firmadaki Görevlerine Göre Dağılımı

\begin{tabular}{|l|r|r|r|}
\hline \multicolumn{1}{|c|}{ Görevler } & Sılklk & Yüzde & \multicolumn{1}{c|}{ Birikimli Yüzde } \\
\hline Firma Sahibi & 45 & 22.0 & 22.0 \\
\hline Genel Müdür & 33 & 16.1 & 38.0 \\
\hline Pazarlama Müdürü & 13 & 6.3 & 44.4 \\
\hline İhracat/İthalat Müdürü & 6 & 2.9 & 47.3 \\
\hline Diğer & 108 & 52.7 & 100.0 \\
\hline Toplam & 205 & 100.0 & \\
\hline
\end{tabular}


Tablo 6'da ankete katılan firmalarda çalışan kişilerin görev dağılımına yer verilmiştir. Ankete katılanlardan \%22’ si firma sahibi, \%16.1’i genel müdür, \%6.3’ü pazarlama müdürü, \%2.9'ü ihracat/ithalat müdürü ve bunların dışında görev yapanların oranı ise \%52.7 ile çoğunluğu oluşturmaktadır.

\subsubsection{Güvenilirlik Analizi Sonuçları}

Araştırmanın güvenilirlik analizi anketin ikinci bölümünde yer alan 5'li Likert ölçeğine göre hazırlanan sorular baz alınarak hesaplanmıştır. Buna göre Güvenilirlik Analizi sonucu aşağıdaki gibidir.

Tablo 7: Güvenilirlik Analizi Sonucu

\begin{tabular}{|r|rr|}
\hline \multicolumn{2}{|r|}{ Cronbach's Alpha } & \multicolumn{1}{|c|}{ Soru Sayısı } \\
\hline & 0.790 & \\
\hline
\end{tabular}

Tablo 7'de araştırmada kullanılan ölçeğin güvenilirliğini belirlemek için, ölçeğin Cronbach Alpha katsayısı belirlenmiştir. Yapılan güvenilirlik analizinin sonucuna göre ölçeğe verilen yanıtlar oldukça güvenilirdir.

\subsubsection{Araştırmaya Katılanların Sorulara Verdiği Yanıtların Frekans Analizi}

Anketin ikinci bölümünde yer alan sorulara Frekans Analizi uygulanmıştır. Sonuçlar aşağıdaki tablo 8'de gösterildiği gibidir.

Ankete katılan firmaların tamamına yakını lojistik kavramı ve lojistik faaliyetler hakkında bilgi sahibidir. Buna göre kesinlikle katılıyorum ve katılıyorum oranı \%93.2 civarındadır. Katılımcılar, firmanın lojistiği her aşamada kullandığını ifade etmişlerdir ve \%60.5 ile kesinlikle katılıyorum seçeneğini işaretlemişlerdir. \%29.3 katılıorum, \%2 kararsızım, \% 8.3'lük oranın ise lojistiği her aşamada kullanmadığı gözlemlenmiştir. Bu sonuçlara göre bölgedeki firmaların büyük çoğunluğunun lojistiği her aşamada kullandığı söylenebilir.

Firmaların, \%38.5'i lojistiği üretim sonrası kullanmadıklarını ifade ederek katılmıyorum seçeneğine yanıt vermişlerdir. \%21'i kesinlikle katılmıyorum, \%18'i kesinlikle katılıyorum, \%17.1'i katılıyorum ve \%5.4 ü ise kararsızım seçeneklerine yanıt vermiştir. Firmaların büyük bir çoğunluğu kesinlikle katılıyorum ve katılıyorum oranı \%96.1 ile karayolunu kullanarak taşıma işlemlerini yerine getirmektedir. Firmaların karayolunu tercih etmesindeki sebep ise coğrafi konum gereği, diğer taşıma şekillerinin çok elverişli olmaması olabilir. Firmaların karayolu dışında diğer taşıma modlarını kullanma seçeneklerine verilen yanıtların \%30.2'si kesinlikle katılmıyorum, \%30.7'si katılmıyorum, \%3.4'ü kararsızım, \%14.6'sı katılıyorum ve \%21'i kesinlikle katılıyorum şeklinde cevaplamıștır. 


\section{Tablo 8: Değişken Soruların Frekans Analizi}

\begin{tabular}{|c|c|c|c|c|c|c|}
\hline DEĞİŞKENLER(SORULAR) & $1 \%$ & $2 \%$ & $3 \%$ & $4 \%$ & $5 \%$ & Toplam \\
\hline 1-Lojistik ve lojistik faaliyetler hakkında bilgi sahibiyim. & - & 2 & 4.9 & 37.6 & 55.6 & 100 \\
\hline 2-Firmamız lojistiği her aşamada kullanmaktadır. & 1 & 7.3 & 2 & 29.3 & 60.5 & 100 \\
\hline 3-Firmamız lojistiği sadece üretim sonrası kullanmaktadır. & 21 & 38.5 & 5.4 & 17.1 & 18 & 100 \\
\hline $\begin{array}{l}\text { 4-Firmamız taşıma modlarından biri olan karayolu } \\
\text { taşımacılığını en fazla kullanmaktadır. }\end{array}$ & - & 3.4 & 0.5 & 16.1 & 80 & 100 \\
\hline $\begin{array}{l}\text { 5-Firmamız denizyolu, havayolu ve demiryolu taşımacılığını } \\
\text { etkin bir şekilde kullanmaktadır. }\end{array}$ & 30.2 & 30.7 & 3.4 & 14.6 & 21 & 100 \\
\hline $\begin{array}{l}\text { 6-Taşımacılık şeklini tercih ederken maliyetin düşük, } \\
\text { güvenilir ve hızlı olması önemlidir. }\end{array}$ & - & 0.5 & 2.4 & 20 & 77.1 & 100 \\
\hline $\begin{array}{l}\text { 7-Taşımacılık şeklini tercih ederken ürünün özelliklerine } \\
\text { uygunluğu ve gönderilecek mal miktarı önemlidir. }\end{array}$ & 0.5 & - & 0.5 & 24.4 & 74.1 & 100 \\
\hline $\begin{array}{l}\text { 8-Lojistik alanda dış kaynaktan taşımacılık hizmeti } \\
\text { alınmaktadır. }\end{array}$ & 9.8 & 11.7 & 6.3 & 26.8 & 45.4 & 100 \\
\hline $\begin{array}{l}\text { 9-Lojistik alanda diş kaynaktan depolama hizmeti } \\
\text { alınmaktadır. }\end{array}$ & 22 & 30.7 & 7.3 & 16.6 & 23.4 & 100 \\
\hline $\begin{array}{l}\text { 10-Lojistik alanda diş kaynaktan ambalajlama/paketleme } \\
\text { hizmeti alınmaktadır. }\end{array}$ & 28.3 & 31.2 & 5.4 & 19 & 16.1 & 100 \\
\hline $\begin{array}{l}\text { 11-Lojistik alanda dış kaynaktan envanter/stok yönetimi } \\
\text { hizmeti alınmaktadır. }\end{array}$ & 33.2 & 30.2 & 5.9 & 15.6 & 15.1 & 100 \\
\hline $\begin{array}{l}\text { 12-Lojistik faaliyetlerin tamamını kendi bünyemizde } \\
\text { gerçekleștirme nedeni daha ucuz ve daha kaliteli oluşudur. }\end{array}$ & 7.8 & 26.8 & 8.8 & 26.8 & 29.8 & 100 \\
\hline $\begin{array}{l}\text { 13-Lojistik faaliyetlerin tamamını dış kaynak kullanarak } \\
\text { gerçekleştirme nedeni daha ucuz ve daha kaliteli oluşudur. }\end{array}$ & 16.6 & 29.8 & 13.2 & 23.4 & 17.1 & 100 \\
\hline $\begin{array}{l}\text { 14-Lojistik faaliyetlerin tamamını dıș kaynak kullanarak } \\
\text { gerçekleștirme nedeni referanslarının güçlü ve lojistik alanda } \\
\text { deneyimli olmasıdır. }\end{array}$ & 14.6 & 29.3 & 10.7 & 27.3 & 18 & 100 \\
\hline $\begin{array}{l}\text { 15-Lojistik faaliyetlerin tamamını dış kaynak kullanarak } \\
\text { gerçekleștirme nedeni fiziksel olarak firmamıza yakın } \\
\text { olmasıdır. }\end{array}$ & 17.6 & 42.9 & 13.2 & 20 & 6.3 & 100 \\
\hline $\begin{array}{l}\text { 16-Lojistik faaliyetlerin tamamını dış kaynak kullanarak } \\
\text { gerçekleştirme nedeni kurumsal çalışması ve finansal } \\
\text { gücünün yüksek olmasıdır. }\end{array}$ & 15.6 & 31.7 & 11.2 & 22.4 & 19 & 100 \\
\hline $\begin{array}{l}\text { 17-Ürettiğimiz her bir ürünün lojistik faaliyetleri, maliyeti } \\
\text { arttırır. }\end{array}$ & 3.4 & 8.8 & 5.4 & 29.8 & 52.7 & 100 \\
\hline $\begin{array}{l}\text { 18-Lojistik maliyetlerin nasıl hesaplandığı yönetici } \\
\text { tarafından bilinmelidir. }\end{array}$ & 0.5 & 1.5 & 0.5 & 29.8 & 67.8 & 100 \\
\hline $\begin{array}{l}\text { 19-Lojistik faaliyetler için hizmet veren işletmeden maliyet } \\
\text { hakkında bilgi alınmalıdır. }\end{array}$ & 0.5 & 1.5 & 4.9 & 30.2 & 62.9 & 100 \\
\hline $\begin{array}{l}\text { 20-Lojistik maliyetler etkin bir şekilde yönetilir ise ürünün } \\
\text { maliyeti azalır. }\end{array}$ & - & 2.4 & 4.4 & 28.3 & 64.9 & 100 \\
\hline $\begin{array}{l}\text { 21-Lojistik maliyetler muhasebe alanına girdiği için toplam } \\
\text { giderle ilişkilidir. }\end{array}$ & 1 & 1.5 & 4.9 & 33.7 & 59 & 100 \\
\hline $\begin{array}{l}\text { 22-Envanter yönetimi doğru planlandığında maliyet avantajı } \\
\text { sağlar. }\end{array}$ & 0.5 & 2 & 6.3 & 32.7 & 58.5 & 100 \\
\hline $\begin{array}{l}\text { 23-Lojistik maliyetlerin etkin bir şekilde yönetilmesi rekabet } \\
\text { gücünü arttırır. }\end{array}$ & - & 2 & 4.4 & 31.7 & 62 & 100 \\
\hline $\begin{array}{l}\text { 24-Lojistik maliyetlerin etkin bir şekilde yönetilmesi } \\
\text { verimliliği arttırır. }\end{array}$ & - & 3.9 & 2.9 & 30.2 & 62.9 & 100 \\
\hline
\end{tabular}


Firmaların taşıma şekillerini seçerken maliyetin düşük, hızlı ve güvenli olması önemlidir sorusuna \%77.1'i kesinlikle katılıyorum, \%20’si katılıyorum, \%2.4’ü kararsızım ve \%0.5’i katılmıyorum diyerek cevap vermiştir. Söz konusu düşük maliyet, hız ve güvenilirlik olunca yaklaşık tüm katılımcılar yani 199 işletme maliyet, hız ve güvenilirliğin önemli olduğunu belirtmiştir. Firmaların taşımacılık şeklini tercih ederken ürünün özelliklerine uygunluğu ve gönderilecek mal miktarının önemli olması sorusuna verdikleri yanıt \%74.1 ile kesinlikle katılıyorum ve \%24.4 ile katılıyorum olmuştur. Katılımcılar için maliyetin yanında ürünün taşınacak araca uygun olması da önemlidir denilebilir.

Firmaların lojistik alanda dış kaynaktan taşımacılık hizmeti aldıkları sonucuna varılmaktadır. Buna göre kesinlikle katılıyorum ve katılıyorum oranı \%72.2 civarındadır. Lojistik alanda dış kaynaktan depolama hizmeti alınmaktadır ifadesine işletmecilerin yarıdan fazlası \%52.7 oranı ile firmalarının depolama hizmeti almadıklarını, kendi bünyelerinde depolama faaliyetlerini gerçekleştirdiklerini ifade etmişlerdir.

Firmaların büyük çoğunluğunun lojistik faaliyetlerden olan ambalajlama hizmetini kendi bünyesinde gerçekleştirerek bu alanda dış kaynak kullanmadıkları gözlemlenmiştir. Oranlara bakıldığında \%16.1'i kesinlikle katılıyorum, \%19'u katılıyorum, \%5.4'ü karasızım, \%31.2'si katılmıyorum ve \%28.3'ü kesinlikle katılmıyorum şeklindedir. Firmaların dış kaynaktan envanter yönetimi hizmeti almadıkları gözlemlenmiştir. Kesinlikle katılmıyorum ve katılmıyorum ifadeleri ile \%63.4 oranına sahiptir. İşletmelerin envanter yönetimini kendi işletme bünyesinde gerçekleştirme sebebi, daha güvenilir olması olabilir.

Firmaların yarısından fazlasının, lojistik faaliyetleri kendi bünyesinde daha ucuz ve kaliteli bir şekilde yerine getirdiği belirtilmiştir. \%29.8'i kesinlikle katılıyorum, \%26.8'i katılıyorum, \%8.8'i kararsızım, \%26.8'i katılmıyorum ve \%7.8’i kesinlikle katılmıyorum şeklinde cevap vermiştir. Lojistik faaliyetlerin tamamını diş kaynak kullanarak gerçekleştirme nedeni daha ucuz ve daha kaliteli oluşudur ifadesine firmaların verdiği yanıtlar \%17.1'i kesinlikle katılıyorum, \%23.4’ü katılıyorum, \%13.2'si kararsızım, \%29.8’i, katılmıyorum ve \%16.6’sı kesinlikle katılmıyorum şeklindedir. Bu sonuçlara göre dış kaynak kullanımının ucuz ve kaliteli olması önemli bir etken olmayabilir.

Lojistik faaliyetlerin tamamını dış kaynak kullanarak gerçekleştirme nedeni referanslarının güçlü ve lojistik alanda deneyimli olmasıdır ifadesine \%18’i kesinlikle katılıyorum, \%27.3'ü katılıyorum, \%10.7'si karasızım, \%29.3'ü katılmıyorum ve \%14.6’sı kesinlikle katılmıyorum şeklinde cevap vermiştir. Katılıyorum ve katılmıyorum seçeneklerine bakıldığında yaklaşık olarak rakamlar birbirine yakındır. Bu nedenle dış kaynak kullanırken referanslarının güçlü ve deneyimli olması katılımcılar açısından baskın bir etken olmadığı kanısına varılmıştır. İşletmeler açısından dış kaynaktan faydalanılan firmanın yakın veya uzak olması çok önemli bir etken olmadığı ifade ediliyor. Buna göre kesinlikle katılmıyorum ve katılmıyorum ifadelerine verilen yaklaşık oran \%60.5'dir.

Lojistik faaliyetlerin tamamını dış kaynak kullanarak gerçekleştirme nedeni kurumsal çalışması ve finansal gücünün yüksek olmasıdır ifadesine firmaların verdiği yanıtlar \% 19’u 
kesinlikle katılıorum, \%22.4'ü katılıorum, \%11.2'si kararsızım, \%31.7'si katılmıyorum ve \%15.6'sı kesinlikle katılmıyorum şeklindedir. Firmaların büyük bir çoğunluğu \%82.5'i ürettiğimiz her bir ürünün, lojistik faaliyetleri maliyetleri arttırır ifadesine katılarak üretim miktarı arttıkça lojistik maliyetlerin de arttığını ifade etmişlerdir.

Firmaların büyük çoğunluğu yöneticilerin lojistik maliyetler hakkında bilgi sahibi olması gerektiğini ifade etmiştir. Buna göre kesinlikle katılıyorum ve katılıyorum oranı yaklaşık \%97.6 civarındadır. İşletmeler lojistik maliyetlerin önemli olduğunu ve bu yüzden maliyet hakkında bilgi alınması gerektiğini ifade etmişlerdir. Firmaların (\%93.2) lojistik maliyetleri etkin bir şekilde yönettikleri takdirde maliyetlerin azalacağını ifade ederek kesinlikle katılıyorum ve katılıyorum seçeneklerini işaretlemişlerdir.

Firmaların büyük çoğunluğu \%92.7 oranı ile lojistik maliyetler muhasebe alanına girdiği için toplam giderle ilişkilidir ifadesine katılmıştır. Firmaların envanter yönetimi doğru planlandığında maliyet avantajı sağlar ifadesine ise \%2.5’i katılmadıklarını, \%6.3’ü kararsız olduklarını, \%32.7'si katılıyorum ve \%58.5'i ise kesinlikle katıldıklarını ifade etmiştir. Firmaların büyük bir çoğunluğunun \%93.7 oranı ile kesinlikle katılıyorum ve katılıyorum cevabı vermesi lojistik maliyetlerin etkin bir şekilde yönetilmesinin firmaya rekabet avantajı sağladığını göstermektedir. İşletmelerin büyük bir çoğunluğu (\%93.1) işletme verimliliği için, lojistik maliyetlerin yönetilmesinin önemli olduğunu ifade etmiştir. \%3.9'u katılmıyorum, \%2.9 kararsızım, \%30.2'si katılıyorum ve \%62.9'u ise kesinlikle katılıyorum şeklinde cevap vermiştir.

\subsubsection{Firmaların Lojistik Faaliyetler Hakkında Bilgi Düzeylerinin Hukuki Durumuna Göre Analizi}

Katılımcıların lojistik faaliyetler hakkında bilgi düzeylerinin hukuki durumuna göre analizi aşağıdaki tabloda gösterilmiştir.

Tablo 9: Firmaların Lojistik Faaliyetleri Hakkında Bilgi Düzeylerinin; Hukuki Durumuna Göre Analizi

\begin{tabular}{|c|c|c|c|c|c|c|c|c|}
\hline & \multirow[t]{2}{*}{$\mathrm{N}$} & \multirow[t]{2}{*}{ Ortalama } & \multirow[t]{2}{*}{ Std. Sapma } & \multirow[t]{2}{*}{ Std. Hata } & \multicolumn{2}{|c|}{ 95\% Güven Aralığında } & \multirow[t]{2}{*}{ Minimum } & \multirow[t]{2}{*}{ Maximum } \\
\hline & & & & & Alt sinir & Üst sinır & & \\
\hline Limited & 102 & 3.7308 & .41554 & .04114 & 3.6492 & 3.8124 & 2.79 & 4.75 \\
\hline Anonim & 83 & 3.9147 & .48346 & .05307 & 3.8091 & 4.0202 & 2.63 & 4.75 \\
\hline Diğer & 19 & 3.6842 & .42590 & .09771 & 3.4789 & 3.8895 & 2.75 & 4.54 \\
\hline Toplam & 204 & 3.8013 & .45326 & .03173 & 3.7387 & 3.8638 & 2.63 & 4.75 \\
\hline
\end{tabular}

Tablo 9'da firmaların hukuki durumu ele alınarak lojistik ve lojistik faaliyetler hakkında bilgi sahibi olup olmadıkları incelenmiştir. Analiz sonucuna göre araştırmaya katılan anonim şirketlerin ortalaması 3.91 iken limited şirketlerin ortalamasının 3.73 olduğu ve bu iki sınıfa girmeyen diğer işletmelerin ortalamasının ise 3.68 ile en düşük olduğu 
görülmektedir. Firmaların anonim ve limited şirketi olmaları, ankete verilen yanıtları etkilemiştir. Bunun nedeni ise bu firmaların pazarda etkin olması ve lojistik faaliyetler hakkında bilgi sahibi olarak ayrı bir lojistik departmanlarına sahip olmaları bu nedenle lojistik maliyetleri etkin bir şekilde yöneterek rekabet açısından avantaj elde etmeleri olabilir.

Tablo 10:Firmaların Hukuki Durumuna Göre Anova Tablosu

\begin{tabular}{|l|r|r|r|r|r|}
\hline & Kareler Toplamı & df & Ortalama Kare & F & Sig. \\
\hline Gruplar Arasında & 1.834 & 2 & .917 & 4.623 & .011 \\
Gruplar İçinde & 39.871 & 201 & .198 & & \\
Toplam & 41.705 & 203 & & & \\
\hline
\end{tabular}

Tablo 10'da Anova analizi sonucunda ankete verilen yanttların ortalaması ile firmaların hukuki durumu arasında anlamlı fark olduğu ortaya çıkmaktadır $(p=0.011)$. Farkın nereden kaynaklandığını anlamak için Scheffe Analizi yapılmıștır. Scheffe Analizi, gruplar arasında ortaya çıkan farkın kaynağına bakmada sıkça kullanılan testlerden biridir (Kayri 2009: 58).

Tablo 11: Firmaların Hukuki Durumuna Göre Scheffe Tablosu

\begin{tabular}{|c|c|c|c|c|c|c|}
\hline \multirow[t]{2}{*}{ (I) Hukuki_Durum } & \multirow[t]{2}{*}{ (J) Hukuki_Durum } & \multirow[t]{2}{*}{$\begin{array}{c}\text { Ortalama Difference } \\
(\mathrm{I}-\mathrm{J})\end{array}$} & \multirow[t]{2}{*}{ Std. Hata } & \multirow[t]{2}{*}{ Sig. } & \multicolumn{2}{|c|}{$\begin{array}{l}\text { 95\% Confidence } \\
\text { Interval }\end{array}$} \\
\hline & & & & & Alt sinır & Üst sınır \\
\hline \multirow{2}{*}{ Limited } & Anonim & $-.18386^{*}$ & .06584 & .022 & -.3462 & -.0215 \\
\hline & Diğer & .04659 & .11129 & .916 & -.2279 & .3210 \\
\hline \multirow{2}{*}{ Anonim } & Limited & $.18386^{*}$ & .06584 & .022 & .0215 & .3462 \\
\hline & Diğer & .23045 & .11327 & .129 & -.0489 & .5098 \\
\hline \multirow{2}{*}{ Diğer } & Limited & -.04659 & .11129 & .916 & -.3210 & .2279 \\
\hline & Anonim & -.23045 & .11327 & .129 & -.5098 & .0489 \\
\hline
\end{tabular}

İşletmelerin hukuki durumu ile sahip oldukları lojistik faaliyetler hakkında bilgi düzeyleri arasındaki ilişkiye bakıldığında anonim şirket üyeleri ile limited şirket üyeleri arasındaki farkın istatistiki olarak anlamlı olduğu görülmektedir $(\mathrm{p}=0.022)$.

\subsubsection{Firmaların Lojistik Faaliyetler Hakkında Bilgi Düzeylerinin Faaliyet Alanına Göre Analizi}

Katılımcıların lojistik faaliyetler hakkında bilgi düzeylerinin faaliyet alanına göre analizi aşağıdaki tabloda gösterilmiştir. 
Tablo 12: Firmaların Lojistik Faaliyetler Hakkında Bilgi Düzeylerinin Faaliyet Alanına Göre Analizi

\begin{tabular}{|c|c|c|c|c|c|c|c|c|}
\hline & \multirow[t]{2}{*}{$\mathrm{N}$} & \multirow[t]{2}{*}{ Ortalama } & \multirow[t]{2}{*}{ Std. Sapma } & \multirow[t]{2}{*}{ Std. Hata } & \multicolumn{2}{|c|}{ 95\% Güven Aralığında } & \multirow[t]{2}{*}{ Minimum } & \multirow[t]{2}{*}{ Maximum } \\
\hline & & & & & Alt sinır & Üst sinır & & \\
\hline Hizmet & 24 & 3.7865 & .53561 & .10933 & 3.5603 & 4.0126 & 2.63 & 4.54 \\
\hline Üretim & 131 & 3.8314 & .45105 & .03941 & 3.7535 & 3.9094 & 2.79 & 4.75 \\
\hline Ticaret & 43 & 3.7510 & .42214 & .06438 & 3.6211 & 3.8809 & 2.75 & 4.63 \\
\hline Diğer & 6 & 3.5625 & .34636 & .14140 & 3.1990 & 3.9260 & 3.17 & 4.00 \\
\hline Toplam & 204 & 3.8013 & .45326 & .03173 & 3.7387 & 3.8638 & 2.63 & 4.75 \\
\hline
\end{tabular}

Tablo 12'de firmaların faaliyet alanı ele alınarak lojistik ve lojistik faaliyetler hakkında bilgi sahibi olup olmadıkları incelenmiştir. Analiz sonucuna göre araştırmaya katılan ve üretim sektöründe faaliyet gösteren firmaların ortalaması 3.83, hizmet sektöründe faaliyet gösteren firmaların ortalaması 3.78 ve ticaret sektöründe faaliyet gösteren firmaların ortalaması ise 3.75 olduğu görülmektedir. Üretim, hizmet ve ticaret sektöründe faaliyet gösteren firmalara bakıldığında ortalamaları birbirine çok yakındır denilebilir. $\mathrm{Bu}$ gruplara girmeyen firmaların ise ortalaması 3.56'dır.

Tablo 13: Firmaların Faaliyet Alanına Göre Anova Tablosu

\begin{tabular}{|l|r|r|r|r|r|}
\hline & Kareler Toplamı & df & Ortalama Kare & F & Sig. \\
\hline Gruplar Arasında & .575 & 3 & .192 & .932 & .426 \\
Gruplar İçinde & 41.130 & 200 & .206 & \\
Toplam & 41.705 & 203 & & \\
\hline
\end{tabular}

Tablo 13'de firmaların lojistik faaliyetler hakkındaki bilgi düzeyleri ile faaliyet alanı karşılaştırıldığında faaliyet alanları arasında istatistiki olarak anlamlı bir farklılık görülmemektedir $(\mathrm{p}=0.426)$. Bunun nedeni ise firmaların faaliyet alanının, lojistik faaliyetler hakkında bilgi sahibi olmasında önemli bir etken olmaması olabilir.

\subsubsection{Firmaların Lojistik Faaliyetler Hakkında Bilgi Düzeylerinin Faaliyet Süresine Göre Analizi}

Katılımcıların lojistik faaliyetler hakkında bilgi düzeylerinin; faaliyet süresine göre analizi aşağıdaki tabloda gösterilmiştir. 
Tablo 14: Firmaların Lojistik Faaliyetler Hakkında Bilgi Düzeylerinin Faaliyet Süresine Göre Analizi

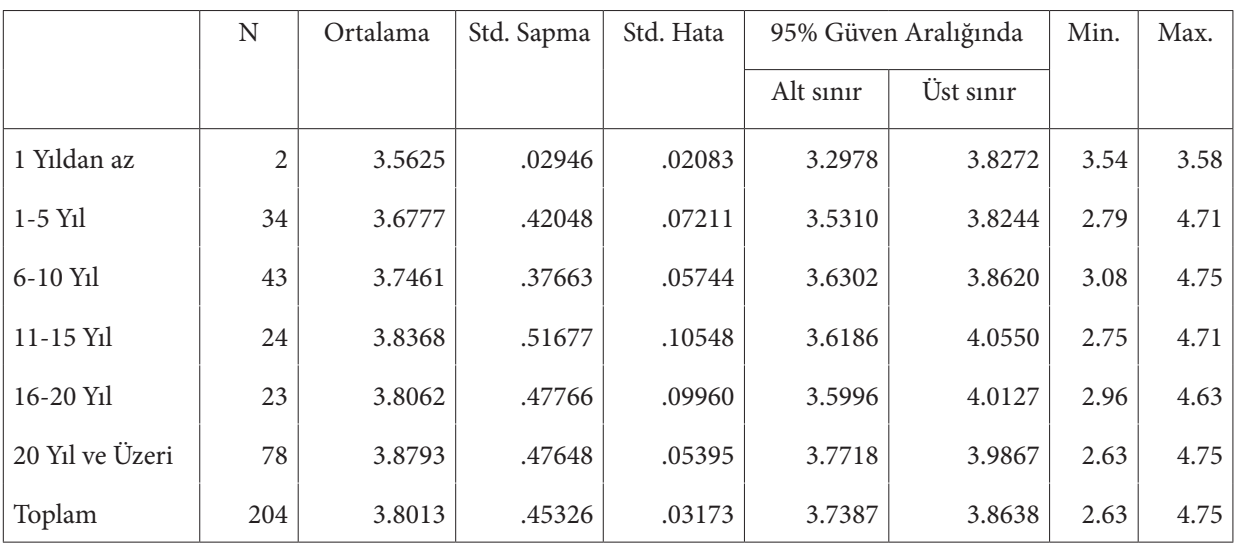

Tablo 14'de firmaların faaliyet süresi ele alınarak lojistik ve lojistik faaliyetler hakkında bilgi sahibi olup olmadıkları incelenmiştir. Analiz sonucuna göre araştırmaya katılan firmaların faaliyet süresi 20 yıl ve üzeri olanların ortalaması 3.87, 16 ile 20 yıl arası olanların ortalaması 3.80, 11 ile 15 yıl arası olanların ortalaması 3.83, 6 ile 10 yıl arası olanların ortalaması 3.74, 1 ile 5 yıl arası olanların ortalaması 3.67 ve 1 yıldan az olanların ise en düşük ortalamaya (3.56) sahip olduğu görülmektedir.

Tablo 15: Firmaların Faaliyet Süresine Göre Anova Tablosu

\begin{tabular}{|l|r|r|r|r|r|}
\hline & Kareler Toplamı & df & Ortalama Kare & F & Sig. \\
\hline Gruplar Arasında & 1.269 & 5 & .254 & 1.243 & .290 \\
Gruplar İçinde & 40.436 & 198 & .204 & \\
Toplam & 41.705 & 203 & & \\
\hline
\end{tabular}

Tablo 15'de firmaların lojistik faaliyetler hakkındaki bilgi düzeyleri ile faaliyet süresi karşılaştırıldığında faaliyette bulunulan yıllar arasında istatistiki olarak anlamlı bir farklılık görülmemektedir $(\mathrm{p}=0.290)$. Bu nedenle firmaların faaliyet süresinin, lojistik faaliyetler hakkında bilgi sahibi olmasında önemli bir etken olarak görülmemektedir denilebilir.

\subsubsection{Firmaların Lojistik Faaliyetler Hakkında Bilgi Düzeylerinin Çalışan Sayısına Göre Analizi}

Katılımcıların lojistik faaliyetler hakkında bilgi düzeylerinin çalışan sayısına göre analizi aşağıdaki tabloda gösterilmiştir. 
Tablo 16: Firmaların Lojistik Faaliyetler Hakkında Bilgi Düzeylerinin; Çalışan Sayısına Göre Analizi

\begin{tabular}{|c|c|c|c|c|c|c|c|c|}
\hline & \multirow[t]{2}{*}{$\mathrm{N}$} & \multirow[t]{2}{*}{ Ortalama } & \multirow[t]{2}{*}{ Std. Sapma } & \multirow[t]{2}{*}{$\begin{array}{l}\text { Std. } \\
\text { Hata }\end{array}$} & \multicolumn{2}{|c|}{$\begin{array}{l}\text { 95\% Güven } \\
\text { Aralığında }\end{array}$} & \multirow[t]{2}{*}{ Minimum } & \multirow[t]{2}{*}{ Maximum } \\
\hline & & & & & Alt sinir & Üst sinır & & \\
\hline 10 Kişiden az & 25 & 3.5717 & .23647 & .04729 & 3.4741 & 3.6693 & 3.13 & 3.96 \\
\hline $11-50$ & 93 & 3.7092 & 44889 & .04655 & 3.6168 & 3.8017 & 2.75 & 4.71 \\
\hline $51-100$ & 34 & 3.9485 & .39235 & .06729 & 3.8116 & 4.0854 & 3.17 & 4.75 \\
\hline $101-150$ & 16 & 4.1146 & .48532 & .12133 & 3.8560 & 4.3732 & 3.33 & 4.75 \\
\hline $151-200$ & 11 & 3.7500 & .53489 & .16128 & 3.3907 & 4.1093 & 2.63 & 4.63 \\
\hline $201-250$ & 4 & 3.7917 & .65881 & .32940 & 2.7434 & 4.8400 & 3.21 & 4.58 \\
\hline 251 ve üzeri & 21 & 4.0337 & .41659 & .09091 & 3.8441 & 4.2234 & 3.21 & 4.67 \\
\hline Toplam & 204 & 3.8013 & .45326 & .03173 & 3.7387 & 3.8638 & 2.63 & 4.75 \\
\hline
\end{tabular}

Tablo 16'da firmaların çalışan sayısı ele alınarak lojistik ve lojistik faaliyetler hakkında bilgi sahibi olup olmadıkları incelenmiştir. Analiz sonucuna göre araştırmaya katılan firmalarda çalışan sayısı 101 ile 150 kişi olanların ortalaması 4.11 iken 250 ve üzeri çalışana sahip firmaların ortalaması 4.03 olmuştur ve analiz sonucu içinde ortalaması en yüksek paya sahiplerdir. Daha sonra ise 3.94 ortalama ile 51-100 kişi, 3.79 ortalama ile 201-250 kişi, 3.75 ortalama ile 151-200 kişi ve 3.70 ortalama ile 11-50 kişi şeklinde görülmektedir. En düşük ortalamaya sahip olan kişi sayısı ise 3.57 ile 10 kişiden az çalışanı olan firmalardır. Bu nedenle çalışan sayısının fazla olması lojistik faaliyetler açısından önemli bir unsur olarak görülebilir.

Tablo 17. Firmaların Çalışan Sayısına Göre Anova Tablosu

\begin{tabular}{|l|r|r|r|r|r|}
\hline & Kareler Toplamı & df & Ortalama Kare & F & Sig. \\
\hline Gruplar Arasında & 5.578 & 6 & .930 & 5.069 & .000 \\
Gruplar İçinde & 36.127 & 197 & .183 & & \\
Toplam & 41.705 & 203 & & & \\
\hline
\end{tabular}

Tablo 17'de firmaların lojistik faaliyetler hakkındaki bilgi düzeyleri ile çalışan sayısına bakıldığında ankete verilen yanıtlarda firmanın çalışan sayısına göre istatistiki olarak anlamlı farklılık göstermektedir $(\mathrm{p}=0.000)$. Farkın nereden kaynaklandığını anlamak için Tamhane testi yapılmış ve bu testin sonucunda anlamlı bir farka rastlanmıştır. Tamhane testi grupların birbirleri ile ikili karşılaştırmalarını yaparak farkın nereden geldiğini göstermektedir. Testin sonuçlarına bakıldığında firmanın çalışan sayısına göre farklılık sebebi şunlardır: 
- 10 kişiden az çalışana sahip firmaların lojistik faaliyetler hakkında bilgi sahibi olması, 51-100 çalışanı ( $\mathrm{p}=0.001), 101-150$ çalışanı $(\mathrm{p}=0.010)$ ile 251 ve üzeri çalışanı $(\mathrm{p}=0.002)$ olan firmaların lojistik faaliyetler hakkında bilgi sahibi olma düzeyi arasında anlamlı fark olmasidir.

- 101-150 çalışana sahip firmaların lojistik faaliyetler hakkında bilgi sahibi olması ile 10 kişiden az çalışanı olan ( $\mathrm{p}=0.010)$ firmaların lojistik faaliyetler hakkında bilgi sahibi olma düzeyi arasında anlamlı fark olmasıdır.

\subsubsection{Firmaların Lojistik Faaliyetler Hakkında Bilgi Düzeylerinin Ankete Katılanların Firmadaki Görevine Göre Analizi}

Katılımcıların lojistik faaliyetler hakkında bilgi düzeylerinin ankete katılanların firmadaki görevine göre analizi aşağıdaki tabloda gösterilmiştir.

Tablo 18: Firmaların Lojistik Faaliyetler Hakkında Bilgi Düzeylerinin Firmadaki Görevine Göre Analizi

\begin{tabular}{|c|c|c|c|c|c|c|c|c|}
\hline & \multirow[t]{2}{*}{$\mathrm{N}$} & \multirow[t]{2}{*}{ Ortalama } & \multirow[t]{2}{*}{ Std. Sapma } & \multirow{2}{*}{$\begin{array}{l}\text { Std. } \\
\text { Hata }\end{array}$} & \multicolumn{2}{|c|}{ 95\% Güven Aralığında } & \multirow[t]{2}{*}{ Minimum } & \multirow[t]{2}{*}{ Maximum } \\
\hline & & & & & Alt sinir & Üst sinır & & \\
\hline Firma Sahibi & 44 & 3.7443 & .37242 & .05614 & 3.6311 & 3.8575 & 2.96 & 4.63 \\
\hline Genel Müdür & 33 & 4.1174 & .50059 & .08714 & 3.9399 & 4.2949 & 3.08 & 4.75 \\
\hline Pazarlama Müdürü & 13 & 4.0032 & .57696 & .16002 & 3.6545 & 4.3519 & 2.63 & 4.71 \\
\hline $\begin{array}{l}\text { İhracat/İthalat } \\
\text { Müdürü }\end{array}$ & 6 & 3.8194 & .29423 & .12012 & 3.5107 & 4.1282 & 3.54 & 4.21 \\
\hline Diğer & 108 & 3.7025 & .41320 & .03976 & 3.6237 & 3.7814 & 2.75 & 4.63 \\
\hline Toplam & 204 & 3.8013 & .45326 & .03173 & 3.7387 & 3.8638 & 2.63 & 4.75 \\
\hline
\end{tabular}

Tablo 18'de katılımcıların firmadaki görevi ele alınarak lojistik ve lojistik faaliyetler hakkında bilgi sahibi olup olmadığı incelenmiştir. Analiz sonucuna göre araştırmaya katılan firmalarda, firma sahibi olanların ortalaması 3.74, genel müdür olanların ortalaması 4.11, pazarlama müdürü ortalaması 4.00, ihracat/ithalat müdürü ortalaması 3.81 ve en düşük ortalamaya sahip olan ise bu görevler dışında kalanların ortalamasıdır (3.70).

Tablo 19: Firmadaki Göreve Göre Anova Tablosu

\begin{tabular}{|l|r|r|r|r|r|}
\hline & Kareler Toplamı & df & Ortalama Kare & F & Sig. \\
\hline Gruplar Arasında & 5.026 & 4 & 1.256 & 6.817 & .000 \\
Gruplar İçinde & 36.679 & 199 & .184 & & \\
Toplam & 41.705 & 203 & & & \\
\hline
\end{tabular}


Tablo 19'da firmaların lojistik faaliyetler hakkındaki bilgi düzeyleri ile firmadaki görevine göre istatistiki olarak anlamlı farklılık göstermektedir $(\mathrm{p}=0.000)$. Farkın nereden kaynaklandığını anlamak için Tamhane testi yapılmıştır. Tamhane testinin sonuçlarına bakıldı̆̆ında firmadaki göreve göre farkın sebebi şu şekildedir: Genel müdür olanların lojistik faaliyetler hakkındaki bilgi düzeyleri ile firma sahibi $(\mathrm{p}=0.0007)$ ve diğer grupta olanların ( $\mathrm{p}=0.001)$ lojistik faaliyetler hakkındaki bilgi düzeyleri arasında anlamlı fark vardır. Tamhane testinin sonuçlarına göre çıkan farklılıkların nedeni firma sahibi ve genel müdürün lojistik faaliyetler hakkında daha fazla bilgiye sahip olması olabilir.

\subsubsection{Firmanın Hukuki Durumunun Deniz-Hava-Demiryolu Taşımacılığını} Etkin Bir Şekilde Kullanıp Kullanmadığı ile Dış Kaynaktan Depolama Hizmeti Alıp Almadığına Göre Analizi

Firmaların hukuki durumunun deniz-hava-demiryolu taşımacılığını etkin bir şekilde kullanıp kullanmadığı ve dış kaynaktan depolama hizmeti alıp almadığı ile karşılaştırılmıştır. Bunun nedeni ise firmanın hukuki durumunun, denizyolu, havayolu ve demiryolu taşımacılığını etkin bir şekilde kullanıp kullanmadığı ile dış kaynaktan depolama hizmeti alıp almadığı üzerindeki etkisini incelemektir. Tablo aşağıdaki gibidir.

Tablo 20: Firmaların Hukuki Durumunun Deniz-Hava-Demiryolu Taşımacılığını Etkin Bir Şekilde Kullanıp Kullanmadı̆̆ı ile Dış Kaynaktan Depolama Hizmeti Alıp Almadığına Göre Analizi

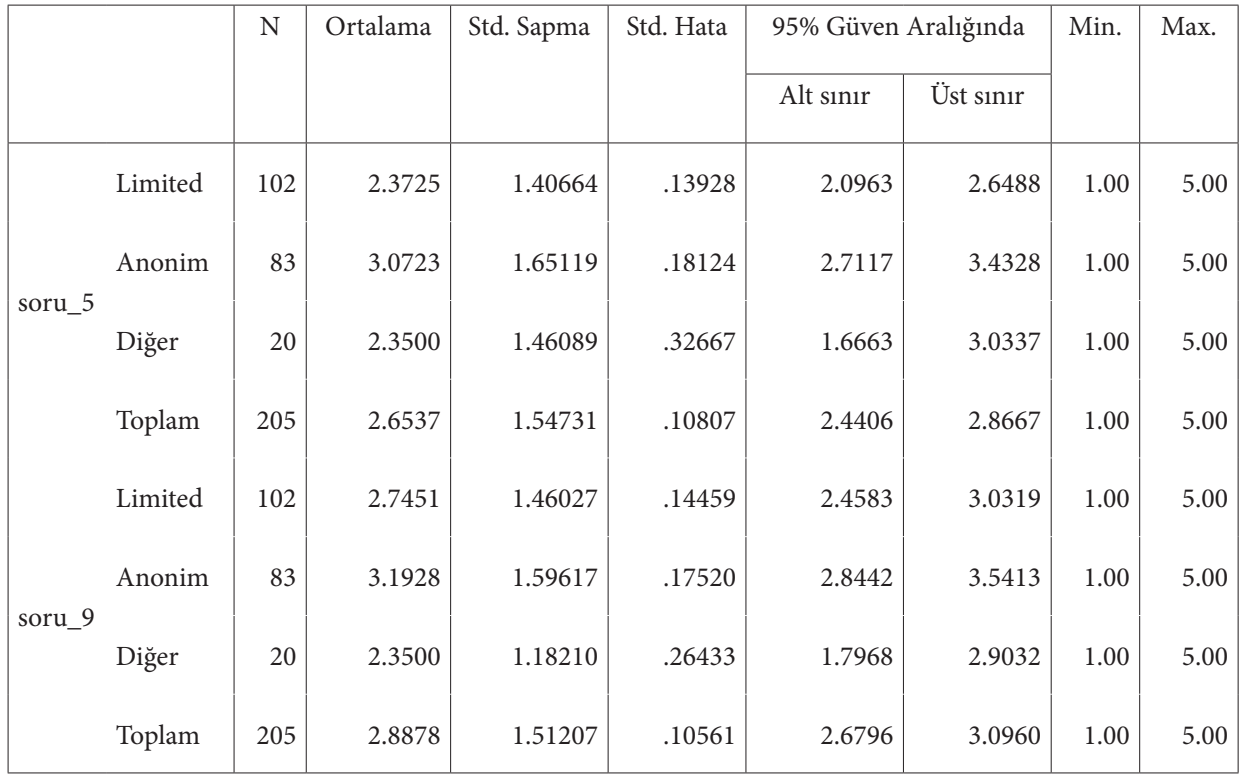

Tablo 20'de firmaların denizyolu, havayolu ve demiryolu taşımacılığını etkin bir şekilde kullanıp kullanmadığg ile firmanın hukuki durumu karşılaştırıldığında limited şirketlerin 
ortalaması 2.37, anonim şirketlerin ortalaması 3.07'dir. Firmanın dış kaynaktan depolama hizmeti alıp almadığı ile firmanın hukuki durumu karşılaştırıldığında limited şirketlerin ortalaması 2.74, anonim şirketlerin ortalaması ise 3.19 olarak gösterilmiştir. Sonuç olarak firmanın hukuki durumunun anonim şirket olması karayolu taşımacılığı dışında diğer taşıma türlerinin de kullanıldığı ve dış kaynaktan depolama faaliyetlerinden faydalanıldığı gözlemlenmiştir.

Tablo 21: Firmanın Hukuki Durumunun Deniz-Hava-Demiryolu Taşımacılığını Etkin Bir Şekilde Kullanıp Kullanmadığı ile Dış Kaynaktan Depolama Hizmeti Alıp Almadığına Göre Anova Tablosu

\begin{tabular}{|c|c|c|c|c|c|c|}
\hline & & Kareler Toplamı & $\mathrm{df}$ & Ortalama Kare & $\mathrm{F}$ & Sig. \\
\hline \multirow{3}{*}{ soru_5 } & Gruplar Arasinda & 24.450 & 2 & 12.225 & 5.323 & .006 \\
\hline & Gruplar İçinde & 463.959 & 202 & 2.297 & & \\
\hline & Toplam & 488.410 & 204 & & & \\
\hline \multirow{3}{*}{ soru_9 } & Gruplar Arasinda & 15.581 & 2 & 7.791 & 3.491 & .032 \\
\hline & Gruplar İçinde & 450.838 & 202 & 2.232 & & \\
\hline & Toplam & 466.420 & 204 & & & \\
\hline
\end{tabular}

Tablo 21'de firmaların hukuki durumunun; deniz-hava-demiryolu taşımacılığını etkin bir şekilde kullanıp kullanmadığı ile dış kaynaktan depolama hizmeti alıp almadığına göre yapılan analiz sonucunda istatistiki olarak anlamlı bir fark olduğu görülmektedir ( $\mathrm{p}=0.006$ $\mathrm{p}=0.032$ ). Farkın nereden kaynaklandığını anlamak için Tamhane testi yapılmıștır.

Tamhane testinin sonuçlarına bakıldığında firmanın hukuki durumu ile denizyolu, havayolu ve demiryolu taşımacılığını etkin bir şekilde kullanıp kullanmadığına göre anonim ve limited şirket üyesi olması arasında anlamlı bir fark olduğu gözlemlenmektedir $(\mathrm{p}=0.008)$. Firmanın hukuki durumu ile dış kaynaktan depolama hizmeti alıp almamasına göre anonim şirket üyesi ve diğer grupta olması arasında anlamlı bir ilişki vardır $(p=0.034)$.

4.5.10. Firmadaki Görevin Lojistik ve Lojistik Faaliyetler Hakkında Bilgi Sahibi Olup Olmamasına, Taşımacılık Şeklini Tercih Ederken Maliyetin Düşük, Güvenilir ve Hızlı Olmasının Önemli Olup Olmamasına, Lojistik Faaliyetler İçin Hizmet Veren İşletmeden Maliyet Hakkında Bilgi Alınıp Alınmamasına Göre Analizi

Katılımcıların firmadaki görevi ile lojistik ve lojistik faaliyetler hakkında bilgi sahibi olup olmadığı karşılaştırılmıştır. Sonuçlar aşağıdaki gibidir. 
Tablo 22: Firmadaki Görevin Lojistik ve Lojistik Faaliyetler Hakkında Bilgi Sahibi Olup Olmamasına Göre Analizi

\begin{tabular}{|c|c|c|c|c|c|c|c|c|c|}
\hline & \multirow[t]{2}{*}{$\mathrm{N}$} & \multirow[t]{2}{*}{ Ortalama } & \multirow[t]{2}{*}{ Std. Sapma } & \multirow[t]{2}{*}{ Std. Hata } & \multicolumn{2}{|c|}{ 95\% Güven Aralığında } & \multirow[t]{2}{*}{ Min. } & \multirow[t]{2}{*}{ Max. } \\
\hline & & & & & & Alt sinır & Üst sinır & & \\
\hline \multirow{6}{*}{ Soru_1 } & Firma Sahibi & 45 & 4.4444 & .62361 & .09296 & 4.2571 & 4.6318 & 2.00 & 5.00 \\
\hline & Genel Müdür & 33 & 4.8182 & .39167 & .06818 & 4.6793 & 4.9571 & 4.00 & 5.00 \\
\hline & $\begin{array}{l}\text { Pazarlama } \\
\text { Müdürï }\end{array}$ & 13 & 4.4615 & .96742 & .26831 & 3.8769 & 5.0461 & 2.00 & 5.00 \\
\hline & $\begin{array}{l}\text { İhracat/İthalat } \\
\text { Müdürü }\end{array}$ & 6 & 4.5000 & .83666 & .34157 & 3.6220 & 5.3780 & 3.00 & 5.00 \\
\hline & Diğer & 108 & 4.3704 & .70502 & .06784 & 4.2359 & 4.5049 & 2.00 & 5.00 \\
\hline & Toplam & 205 & 4.4683 & .68257 & .04767 & 4.3743 & 4.5623 & 2.00 & 5.00 \\
\hline
\end{tabular}

Tablo 22'de firmadaki görevi genel müdür olanların ortalaması 4.81, ihracat/ithalat müdürü olanların ortalaması 4.50, pazarlama müdürü olanların ortalaması 4.46, firma sahibi olanların ortalaması 4.44 ve diğer grupta yer alanların ortalaması ise 4.37 'dir. Genel müdür ortalamasının yüksek olmasının nedeni firma içindeki faaliyetler hakkında bilgi sahibi olması ve etkin bir şekilde firmayı yönetmesidir denilebilir.

Tablo 23: Firmadaki Görevin Taşımacılık Şeklini Tercih Ederken Maliyetin Düşüik, Güvenilir ve Hızlı Olmasının Önemli Olup Olmamasına Göre Analizi

\begin{tabular}{|c|c|c|c|c|c|c|c|c|c|}
\hline & \multirow[t]{2}{*}{$\mathrm{N}$} & \multirow[t]{2}{*}{ Ortalama } & \multirow[t]{2}{*}{$\begin{array}{l}\text { Std. } \\
\text { Sapma }\end{array}$} & \multirow[t]{2}{*}{$\begin{array}{l}\text { Std. } \\
\text { Hata }\end{array}$} & \multicolumn{2}{|c|}{$\begin{array}{l}\text { 95\% Güven } \\
\text { Aralığında }\end{array}$} & \multirow[t]{2}{*}{ Min. } & \multirow[t]{2}{*}{ Max. } \\
\hline & & & & & & Alt sinır & Üst sinır & & \\
\hline \multirow{6}{*}{ Soru_6 } & Firma Sahibi & 45 & 4.7333 & .57997 & 08646 & 4.5591 & 4.9076 & 2.00 & 5.00 \\
\hline & Genel Müdür & 33 & 4.9394 & 24231 & . 04218 & 4.8535 & 5.0253 & 4.00 & 5.00 \\
\hline & Pazarlama Müdürü & 13 & 4.8462 & .37553 & 10415 & 4.6192 & 5.0731 & 4.00 & 5.00 \\
\hline & $\begin{array}{l}\text { İhracat/İthalat } \\
\text { Müdürü }\end{array}$ & 6 & 5.0000 & . 00000 & . 00000 & 5.0000 & 5.0000 & 5.00 & 5.00 \\
\hline & Diğer & 108 & 4.6481 & .56889 & . 05474 & 4.5396 & 4.7567 & 3.00 & 5.00 \\
\hline & Toplam & 205 & 4.7366 & .52289 & .03652 & 4.6646 & 4.8086 & 2.00 & 5.00 \\
\hline
\end{tabular}

Tablo 23'de firmadaki görevi ihracat/ithalat müdürü olanların ortalaması 5.00, genel müdür olanların ortalaması 4.93, pazarlama müdürü olanların ortalaması 4.84, firma sahibi olanların ortalaması 4.73 ve diğer görevde olanların ortalaması 4.64 'tür. İhracat/ ithalat müdürünün ortalamasının yüksek olmasının nedeni ürünün hazırlandıktan sonra sevkiyatı yani müşteriye ulaştırılması aşamasında sürece hakim olması, buna bağlı olarak da nakliye/sevkiyat sürecinin güvenli, hızlı ve düşük maliyetli bir şekilde yerine getirilmesi olabilir. 
Tablo 24: Firmadaki Görevin, Lojistik Faaliyetler İçin Hizmet Veren İşletmeden Maliyet Hakkında Bilgi Alınıp Alınmamasına Göre Analizi

\begin{tabular}{|c|c|c|c|c|c|c|c|c|c|}
\hline & & $\mathrm{N}$ & Ortalama & Std. & Std. & 95\% Güver & Aralığında & Min & Max. \\
\hline & & & & Sapma & Hata & Alt sinır & Üst sınır & & \\
\hline & Firma Sahibi & 45 & 4.5111 & .75745 & .11291 & 4.2835 & 4.7387 & 2.00 & 5.00 \\
\hline & Genel Müdür & 33 & 4.8788 & .33143 & .05770 & 4.7613 & 4.9963 & 4.00 & 5.00 \\
\hline & Pazarlama Müdürü & 13 & 4.7692 & .43853 & .12163 & 4.5042 & 5.0342 & 4.00 & 5.00 \\
\hline Soru_19 & $\begin{array}{l}\text { İhracat/İthalat } \\
\text { Müdürü }\end{array}$ & 6 & 4.6667 & .51640 & .21082 & 4.1247 & 5.2086 & 4.00 & 5.00 \\
\hline & Diğer & 108 & 4.4074 & .76166 & .07329 & 4.2621 & 4.5527 & 1.00 & 5.00 \\
\hline & Toplam & 205 & 4.5366 & .70355 & .04914 & 4.4397 & 4.6335 & 1.00 & 5.00 \\
\hline
\end{tabular}

Tablo 24'de firmadaki görevi genel müdür olanların ortalaması 4.87, pazarlama müdürü olanların ortalaması 4.76, ihracat/ithalat müdürü olanların ortalaması 4.66, firma sahibi olanların ortalaması 4.51 ve diğer görevlerde olanların ortalaması 4.40’tır. Genel müdür ortalamasının yüksek olmasının nedeni ise firmada maliyet kalemleri hakkında bilgi sahibi olması olabilir.

Tablo 25: Firmadaki Görevin Lojistik ve Lojistik Faaliyetler Hakkında Bilgi Sahibi Olup Olmamasına, Taşımacılık Şeklini Tercih Ederken Maliyetin Düşük, Güvenilir ve Hızlı Olmasının Önemli Olup Olmamasına, Lojistik Faaliyetler İçin Hizmet Veren İşletmeden Maliyet Hakkında Bilgi Alınıp Alınmamasına Göre Anova Tablosu

\begin{tabular}{|ll|r|r|r|r|r|}
\hline & Kareler Toplamı & Df & Ortalama Kare & F & \multicolumn{1}{c|}{ Sig. } \\
\hline & Gruplar Arasında & 5.108 & 4 & 1.277 & 2.840 & .025 \\
Soru_1 & Gruplar İçinde & 89.936 & 200 & .450 & & \\
& Toplam & 95.044 & 204 & & & \\
& Gruplar Arasında & 2.775 & 4 & .694 & 2.618 & .036 \\
Soru_6 & Gruplar İçinde & 53.001 & 200 & .265 & & \\
& Toplam & 55.776 & 204 & & & \\
& Gruplar Arasında & 6.501 & 4 & 1.625 & 3.441 & .010 \\
& Gruplar İçinde & 94.475 & 200 & .472 & & \\
Soru_19 & Toplam & 100.976 & 204 & & & \\
& & &
\end{tabular}

Tablo 25'de firmadaki görevin lojistik ve lojistik faaliyetler hakkında bilgi sahibi olup olmamasına, taşımacılık şeklini tercih ederken maliyetin düşük, güvenilir ve hızlı 
olmasının önemli olup olmamasına, lojistik faaliyetler için hizmet veren işletmeden maliyet hakkında bilgi alınıp alınmamasına göre verilen yanıtların ortalaması ile istatistiki olarak anlamlı bir fark vardır $(\mathrm{p}=0.025 \mathrm{p}=0.036 \mathrm{p}=0.010)$. Tamhane testi sonuçlarına göre farkın sebepleri aşağıdaki gibidir:

- Firma sahibinin, lojistik ve lojistik faaliyetler hakkında bilgi sahibi olması ile genel müdür olması arasında anlamlı fark vardır $(\mathrm{p}=0.018)$. Firmada diğer görevi olanların ortalaması ile genel müdür olanların ortalaması arasında da anlamlı bir fark olduğu gözlemlenmektedir ( $\mathrm{p}=0.000)$.

- Firma sahibinin taşımacılık şeklini tercih ederken maliyetin düşük, güvenilir ve hızlı olmasına önem vermesi ile ihracat/ithalat müdürü arasında anlamlı fark vardır $(\mathrm{p}=0.035)$. Genel müdür olanların ortalamasına göre diğer olanların ortalaması arasında da anlamlı fark olduğu gözlemlenmektedir $(\mathrm{p}=0.000)$.

- Firma sahibinin lojistik faaliyetler için hizmet veren işletmeden maliyet hakkında bilgi alması düzeyi ile genel müdürün lojistik faaliyetler için hizmet veren işletmeden maliyet hakkında bilgi alması arasında anlamlı bir fark vardır ( $\mathrm{p}=0.050)$. Genel müdür olanların ortalaması ile diğer olanların ortalaması arasında da anlamlı bir fark olduğu gözlemlenmiştir $(\mathrm{p}=0.000)$.

\section{SONUÇ}

Bu çalışmada, işletmelerin lojistik hakkındaki bilgileri, lojistik faaliyetleri ve bu faaliyetleri nereden karşıladıkları ile lojistik faaliyetler sonucu ortaya çıkan maliyetlerin önemine yönelik çalışılmıştır. Araştırma alanı olarak TR22 Bölgesinde (GMKA’nın TR22 Düzey 2 Bölgesi olarak isimlendirdiği Güney Marmara Bölgesi, Balıkesir (TR221) ve Çanakkale (TR222) illerinden oluşmaktadır) faaliyet gösteren işletmeler seçilmiştir.

Araştırmada kullanılan değişkenlere Güvenilirlik analizi yapılmıştır. Cronbach's Alpha değeri değişkenler için oldukça güvenilir çıkmıştır $(\alpha=0.790)$. Anket değişkenleri için Frekans analizi yapılmış ve oranlar ayrı ayrı yüzdesel olarak hesaplanmıştır. Daha sonra Likert ölçekli sorular ile katılımcıların demografik özellikleri arasında ilişkiye bakılarak Tek Yönlü Varyans Analizi (Anova), Tamhane ve Scheffe Analizleri yapılmıştır. Araştırmada öne çıkan noktalar şu şekilde özetlenebilir;

- Araştırmaya katılanların demografik dağılımlarına bakıldığında katılımcıların \%49,8’i limited şirket üyesi, \%63.9'u üretim sektöründe faaliyet gösteren ve \%45.8’i çalışan sayısı 11 ile 50 kişi olan işletmeler çoğunluktadır.

- Faaliyet süresi ise en fazla \%38.5 ile 20 yıl ve üzeri faaliyet gösteren firmalardan oluşmaktadır. Katılımcıların firmadaki görevinin \%52.7’si diğer grupta yer alan 
görevlerden oluşmaktadır. Bu gruba giren görevler içinde, muhasebe, satış sorumlusu, sevkiyat sorumlusu ve lojistik müdürü yer almaktadır.

- Katılımcıların lojistik faaliyetler hakkında bilgi düzeylerinin hukuki durumuna $(\mathrm{p}=0.011)$, çalışan sayısına $(\mathrm{p}=0.000)$ ve firmadaki görevine $(\mathrm{p}=0.000)$ göre anlamlı bir fark vardır.

- Katılımcıların lojistik faaliyetler hakkında bilgi düzeylerinin firmanın faaliyet alanına $(\mathrm{p}=0.0426)$ ve faaliyet süresine $(\mathrm{p}=0.290)$ göre ise anlamlı bir fark bulunmamaktadır.

- Firmanın hukuki durumuna göre denizyolu, havayolu ve demiryolu taşımacılığını etkin bir şekilde kullanıp kullanmadığı $(\mathrm{p}=0.006)$ ile firmanın dış kaynaktan depolama hizmeti alıp almadığı $(\mathrm{p}=0.032)$ arasında anlamlı bir fark vardır.

- Firmadaki görevin lojistik ve lojistik faaliyetler hakkında bilgi sahibi olup olmamasına $(\mathrm{p}=0.025)$, taşımacılık şeklini tercih ederken maliyetin düşük, güvenilir ve hızlı olmasının önemli olup olmamasına $(\mathrm{p}=0.036)$ ve lojistik faaliyetler için hizmet veren işletmeden maliyet hakkında bilgi alınıp alınmaması $(\mathrm{p}=0.010)$ arasında anlamlı bir fark bulunmaktadir.

Günümüzde küresel rekabette lojistik faaliyetler ve bu faaliyetlerin maliyeti işletmeler açısından önemli bir maliyet unsuru haline gelmiştir. Bu bağlamda işletmelerde ayrı lojistik birimlerin oluşturulması, bu birimlerdeki personele gerekli eğitimlerin verilmesi veya ilgili okullardan mezun olan kişilerin görev alması ve lojistik maliyetlerin yönetimine ilişkin uygulamaya dönük çalışmaların yapılması faydalı olacaktır. 


\section{KAYNAKÇA}

Demir, V. (2008). Lojistik Yönetiminde Maliyet Hesaplaması. 2. Baskı, Ankara: Nobel Yayın Dağıtım.

Demir, V. (2006). Lojistik Faaliyetler ve Maliyetleri. Mali Çözüm SMMMO Yayın Organı, Sayı: 74.

Deran, A., Arslan, S. ve Köksal, A. (2014). Isşletmelerde Lojistik Maliyetlerin Hesaplanması, Konya: Eğitim Yayınevi.

Ener, T. (2010). Küresel Lojistik Performans İndeksi: Mersin'de Faaliyet Gösteren Lojistik Firmalarının Sektörel Performanslarının İncelenmesi. Yüksek Lisans Tezi. Mersin Üniversitesi Sosyal Bilimler Enstitüsü İşletme Ana Bilim Dalı, Mersin.

Gümüş, Y. (2009). Lojistik Faaliyetlerin Rekabet Stratejileri ve İşletme Karı İle Olan İlişkisi. Muhasebe ve Finans Dergisi, Sayı:41, 97-113.

Gümüş, Y. (2007). Lojistik Maliyetlerinin Faaliyet Tabanlı Maliyetleme Yöntemine Göre Hesaplanması ve Bir Üretim İşletmesi Uygulaması. Dayanışma Dergisi, Sayı: 100, $1-24$.

Hacırüstemoğlu, R. ve Şakrak, M. (2002). Maliyet Muhasebesinde Güncel Yaklaşımlar. İstanbul: Türkmen Kitabevi.

Karacan, S. ve Kaya, M. (2011). Lojistik Faaliyetlerde Maliyetleme. 1. Bask1, Kocaeli: Umuttepe Yayınları.

Kayabaşı, A. (2007). İşletmelerde Rekabet Gücünün Geliştirilmesinde Lojistik Faaliyetlerin Performansının Arttırılması: Üretim İşletmeleri Üzerinde Bir Uygulama. Doktora Tezi. Dokuz Eylül Üniversitesi, İzmir.

Kayri, M. (2009). Araştırmalarda Gruplar Arası Farkın Belirlenmesine Yönelik Çoklu Karşılaştırma (POST-HOC) Teknikleri. Fırat Üniversitesi Sosyal Bilimler Dergisi, Cilt: 19, Say1: 1, 51-64.

Lin, B., Collins, J. ve Su, R.K. (2001). Supply Chain Costing: An Activity-Based Perspective. International Journal of Physical Distribution \& Logistics Management, Vol: 31, Issue: 10, 702-713.

Manunen, O. (2000). An Activity-Based Costing Model for Logistics Operations of Manufacturers and Wholesalers. International Journal of Logistics Research and Applications, Vol: 3, Issue: 1, 53-65.

Özcan, S. (2008). Küçük ve Orta Büyüklükteki İşletmelerde Lojistik Yönetiminin Önemi. Mustafa Kemal Üniversitesi Sosyal Bilimler Enstitüsü Dergisi, Cilt: 5, Sayı: 10, 276-300.

Şengel, S. (2012). Lojistik İşletmelerde Performans Değerlemede Lojistik Rasyoların Önemi ve Bir Araştırma. 1. Baskı, Ankara: Detay Yayıncılık.

Taşkın, E. ve Durmaz, Y. (2012). Lojistik Faaliyetler. 1. Baskı, Ankara: Detay Yayıncılı. 
Tseng, Yung-yu.,Taylor, M.A.P. ve Yue, W.L. (2005). The Role Of Transportation In Logistics Chain. Proceedings of the Eastern Asia Society for Transportation Studies, Vol: 5, 1652-1672.

Tokay, S.H., Deran, A., Ceran, Y. ve Demir, V. (2012). Lojistik Maliyetleri ve Raporlama-I. 1. Baskı, Eskişehir: Anadolu Üniversitesi Yayını No: 2549, Açıöŏretim Fakültesi Yayını No: 1519.

Tokay, S.H., Deran, A. ve Arslan, S. (2011). Lojistik Maliyet Yönetiminde İzlenebilecek Stratejiler ve Muhasebe Eğitiminden Beklentiler. Dumlupinar Üniversitesi Sosyal Bilimler Dergisi, Say1: 29, 225-244.

Yaprak, N. (2010). Lojistik Yönetiminin İşletmelerin Rekabet Gücü Üzerindeki Etkisini Ölçmeye Yönelik Bir Uygulama. Yüksek Lisans Tezi. Kırıkkale Üniversitesi Sosyal Bilimler Enstitüsü İşletme Ana Bilim Dalı, Kırıkkale. 